\title{
MARKET ANALYSIS AND MEAL READY-TO-EAT MAIN COURSE DEVELOPMENT IN THE CONTEXT OF MILITARY USE
}

\author{
Ėvalds Raits ${ }^{1,2, \#, ~ A s n a t e ~ K ̧ i r s e-O z o l i n a a ~}{ }^{1}$, and Sandra Muižniece-Brasava ${ }^{1}$ \\ ${ }^{1}$ Faculty of Food Technology, Latvia University of Life Sciences and Technologies, 22 Rìgas Str., Jelgava, LV-3004, LATVIA \\ ${ }^{2}$ Kronis Ltd., 8 Dārznieku Str., Bauska, LV-3901, LATVIA \\ \# Corresponding author, evalds.raits@gmail.com
}

Contributed by Sandra Muižniece-Brasava

\begin{abstract}
A one-day ration can be supplied to a soldier in the form of one ration pack for 24 hours or three packs of meal ready-to-eat, which equals one 24-hour ration. Based on the physical activity level and consequently energy requirements, there are two categories of military operations: a) normal operations, comparable to urban police work or firefighting, and b) combat operations which represent missions involving light-infantry. The aim of this study was: a) to analyse the EU market on the subject of a main course $(M C)$ product in flexible packaging $(n=184)$, in the context of military use, and b) to develop thermostabilised MC aligning with modern health and nutrition recommendations for military use, i.e. protein, carbohydrate, fat, total energy intake, and essential amino acid composition. The greatest amount of ready-to-eat meals with shelf-life over one year are produced in the United Kingdom $(n=48)$ and most of the MC meals are preserved using freeze-drying $(n=135)$. While $90 \%$ of analysed products meet fat criteria for a physically active consumer (i.e. soldier), 39\% meet carbohydrate criteria, $21 \%$ meet energy intake criteria, only $1 \%$ of the products are able to fulfill protein requirements. In this study, nine MC meals with shelf-life of three years were developed, which provide the necessary protein amount for a highly physically active consumer and cover its daily essential amino acid requirements.
\end{abstract}

Keywords: nutritional value, protein content, amino acid, retort pouch, sterilisation.

\section{INTRODUCTION}

In accordance with the guidelines for supply from Requirements of Individual Operations for Military Use, a one-day ration can be supplied to the soldier in a form of one ration pack for 24 hours, or in a way of three meal bags that are equal to one 24-hour ration (NATO, 2013). The aim of the meal ready-to-eat (MRE) is to provide military with adequate nutrition to maintain good health, performance, mental function and morale in the field environment (NATO, 2010).

Based on physical activity level and consequently energy requirements (Table 1), military operations could be divided into two categories: "normal" operations, which are comparable to urban police work or firefighting, and "combat" operations, which represent missions involving light-infantry. The necessary energy amount for a soldier during normal operations has been determined as $\sim 3600 \mathrm{kcal} /$ day $(15.1$
$\mathrm{MJ} /$ day) and $4900 \mathrm{kcal} / \mathrm{day}(20.5 \mathrm{MJ} / \mathrm{day})$ during the combat operations (NATO, 2010).

Table 1. Nutrition requirements summary

\begin{tabular}{|c|c|c|c|c|}
\hline Requirements & $\begin{array}{c}\text { Energy } \\
\text { value, } \\
\text { kcal }\end{array}$ & $\begin{array}{l}\text { Protein, } \\
\mathrm{g}\end{array}$ & $\begin{array}{c}\text { Carbo- } \\
\text { hydrates, } \\
\mathrm{g} \\
\end{array}$ & $\begin{array}{c}\text { Fat, } \\
\mathrm{g}\end{array}$ \\
\hline $\begin{array}{l}\text { Man, } 75 \mathrm{~kg} \text {, active or } \\
\text { moderately active lifestyle }^{1}\end{array}$ & 3300 & 103 & 536 & 83 \\
\hline $\begin{array}{l}\text { Man, } 75 \mathrm{~kg} \text {, vigorous or } \\
\text { vigorously active lifestyle }\end{array}$ & 3800 & 119 & 618 & 95 \\
\hline $\begin{array}{l}\text { Woman, } 60 \mathrm{~kg} \text {, active or } \\
\text { moderately active lifestyle }\end{array}$ & 2550 & 80 & 414 & 64 \\
\hline $\begin{array}{l}\text { Woman, } 60 \mathrm{~kg} \text {, vigorous or } \\
\text { vigorously active lifestyle }\end{array}$ & 2950 & 92 & 479 & 74 \\
\hline Combat operations $^{2}$ & 4900 & $158-185$ & $550-800$ & $110-190$ \\
\hline Normal operations ${ }^{2,3}$ & 3600 & $118-185$ & $404-584$ & $54-140$ \\
\hline
\end{tabular}


Nutrition guidelines for military use (NATO, 2013) are based mainly on Australian and New Zealand (2006) national recommendations (NHMRC, 2006), where energy requirements are estimated based on body mass index (BMI) and physical activity level (PAL). Fundamentally, protein requirements are based on extrapolation of nitrogen losses in the human body in conditions of insufficient protein consumption on a regular basis (FAO/WHO/UNU, 2007). The desired minimal amount recommended for athletes is 1.5 $\mathrm{g} / \mathrm{kg}$ body weight per day (Rodriguez, 2009). Carbohydrates and fat consumption requirements are based on recommended nutrient ration intake, where carbohydrates should provide $45-65 \%$ of total dietary energy intake, and fat should provide $<35 \%$ of total energy amount. Dietary fibre recommended daily intake is $30 \mathrm{~g} /$ day. Regarding sodium consumption, the recommended amount is $2.3-12 \mathrm{~g}$, with a specific remark that main course (MC) should provide at least the minimal amount, and the rest should be achievable individually in an optional way, i.e. seasoning, salt. Such a huge range is justified by the fact that NATO includes countries with different cultures and diverse eating patterns, as well as salt consumption habits (NATO, 2013).

It is crucial for MRE to provide a soldier with appropriate nutrition during the mission. Amino acids (AAs) play a major role in the growth and maintenance processes in a human body. AAs, which are not synthesised in the human body are called essential and must be consumed with food, i.e. by consuming proteins. Essential amino acids, and their required amounts, are summarised in Table 2 . For necessary daily AAs amount calculations, a median weight for a male soldier was taken as $79 \mathrm{~kg}$.

The aim of this study was: a) to analyse EU market on the subject of main course (MC) products in flexible packaging $(\mathrm{n}=184)$, in the context of military use, and b) to develop thermostabilised MC aligning with modern health and nutrition recommendations for military use, i.e. protein, carbohydrate, fat, total energy intake and essential amino acid composition.

Table 2. Amino acid (AA) requirements based on body weight ${ }^{1}$

\begin{tabular}{l|c|c}
\hline \multirow{2}{*}{ AA } & \multicolumn{2}{|c}{ AA requirement, per bodyweight, per day } \\
\cline { 2 - 3 } & $\mathrm{mg} / \mathrm{kg}$ & $\mathrm{mg} / 79 \mathrm{~kg}$ \\
\hline Lysine & 30 & 2370 \\
Leucine & 39 & 3081 \\
Isoleucine & 20 & 1580 \\
Valine & 26 & 2054 \\
Threonine & 15 & 1185 \\
Tyrosine & 25 & 1975 \\
Tryptophan & 4 & 316 \\
Methionine & 10.1 & 798 \\
Cysteine & or & or \\
Histidine & 4.1 & 324 \\
\end{tabular}

${ }^{1} \mathrm{FAO} / \mathrm{WHO} / \mathrm{UNU}, 2007$

\section{MATERIALS AND METHODS}

Framework formulation. During the development of the MRE for "normal operations", it was decided to choose a $\mathrm{MC}$ as the main protein source, which should cover the necessary protein amounts if consumed thrice a day, 370-400 g each time, i.e. in the morning, during the day and in the evening. Based on possible MRE variations, where each MRE consists of a MC, chocolate bar, nuts or raisins, wholegrain bread; MC nutrition requirements were formulated as stated below:

- Energy value, kcal: min $140 \mathrm{kcal} \cdot 100 \mathrm{~g}^{-1}$

- Protein, g: 10.0-14.3 g.100 g ${ }^{-1}$;

- Carbohydrates, g: max $12.5 \mathrm{~g} \cdot 100 \mathrm{~g}^{-1}$;

- Fat, g: 8.4 g.100 g ${ }^{-1}$.

In this work, no strict threshold for dietary fibre and salt was defined, however, dietary fibre and salt content were analysed as optional nutrients. The recommended daily dietary fibre amount is $30 \mathrm{~g}$. Salt consumption should not exceed 12 g/day (NATO, 2013). Other micro- and macronutrients are not discussed in this work.

Market research. Market analysis was performed through the perspective of a previously formulated framework, by studying Europe's largest retail shop (such as Carrefour, Coop etc.) online stores during the period October 2019 April 2020, on the subject of ready-to-eat meals with long shelf-life (i.e. $>2$ years) at ambient temperature. During the analysis, a data base of 14 brands was created (Table 3) forming 184 samples, focusing on nutrient amount and the energy value of ready-to-eat products. Dried product data was acquired after adding water as described on the packaging. Further, market research data was analysed in terms of previously described requirements for product formulation.

MC development. Sufficient nutrient density is the main challenge during the development of functional products for physically active consumer. The Baltic region traditional cuisine consists of agricultural products with meat/fish as conventional protein sources in most dishes.

Therefore, it was decided to place at minimal threshold of meat/fish content in $\mathrm{MC}$ as $30 \%$.

Such an amount (30\% of meat) is able to provide $6 \pm 1 \mathrm{~g}$ of protein per $100 \mathrm{~g}$ of the product, which leads to a conclusion that a side dish should provide at least $4 \mathrm{~g}$ of protein per $100 \mathrm{~g}$ of the product. On the production scale, technological conditions necessitate to pump the garnish in a form of a suspension, where the solid part is garnish, and the liquid part is water in the amount that garnish is able to soak during the sterilisation process. For dishes consisting of garnish that is not able to provide the necessary protein amount, protein concentrates were added. The most suitable way to add whey protein concentrate in our case was to add a sauce to the dish, for example, by substituting milk in a recipe of béchamel sauce with water and whey protein con- 
Table 3. Analysed brands

\begin{tabular}{|c|c|c|c|}
\hline Country of origin & Brand name & Products analysed & Preservation technology \\
\hline Czech republic & Adventure menu ${ }^{1}$ & 12 & Vacuum drying \\
\hline Estonia & Tactical foodpack ${ }^{2}$ & 15 & Freeze-drying \\
\hline Germany & Trek'n'Eat ${ }^{4}$ & 22 & Freeze-drying \\
\hline Netherlands & Adventure food ${ }^{5}$ & 14 & Vacuum drying \\
\hline Norway & Real turmat $^{6}$ & 19 & Freeze-drying \\
\hline Norway & Real field meal $^{6}$ & 19 & Freeze-drying \\
\hline Poland & LYO FOOD $^{7}$ & 15 & Freeze-drying \\
\hline Sweden & gooh! $!^{8}$ & 11 & Pulsed electric field \\
\hline United Kingdom & Expedition foods ${ }^{9}$ & 16 & Freeze-drying \\
\hline United Kingdom & Firepot $^{10}$ & 10 & Freeze-drying \\
\hline United Kingdom & Summit to eat ${ }^{11}$ & 10 & Freeze-drying \\
\hline United Kingdom & Ready to eat Wet meal ${ }^{13}$ & 5 & Retort sterilisation \\
\hline
\end{tabular}

\footnotetext{
${ }^{1}$ Adventure menu. https://adventure-menu.com/ (here and further accessed 9 September $2021{ }^{2}$ Tactical foodpack, accessed 9 September 2021. https://www.tacticalfoodpack.com/ ; ${ }^{3}$ Bla Band. https://scandinavianoutdoor.com/bla-band/ ; ${ }^{4}$ Trek'n'Eat. https://www.katadyngroup.com/ ; ${ }^{5}$ Adventure food. https://adventurefood.com ; ${ }^{6}$ Drytech. https://realoutdoorfood.com/ ; ${ }^{7}$ LYO FOOD. https://lyofood.com/?languageselected ; ${ }^{8}$ gooh! https://www.gooh.se/; 9 Expedition foods. https://expeditionfoods.com/; ${ }^{10}$ Firepot. https://www.firepotfood.com/ ; ${ }^{11}$ Summit to eat. https://www.summittoeat.com/ ; ${ }^{12}$ Wayfarer. https://wayfarer.nianticlabs.com/ ; ${ }^{13}$ MREmountain. https://mremountain.eu
}

centrate, or by substituting legumes with pea or bean protein.

The product development process was divided into three stages:

1) During the theoretical stage, the most interesting and promising dishes for a Latvian consumer were chosen as the target products. To calculate theoretical recipe nutritional value, a data-base with nutritional value and AA profile of each ingredient was created.

2) Each recipe was developed practically on the laboratory scale with consequent organoleptic evaluation process.

3) During the manufacturing-scale experiment stage, each MC was produced in the same environment as it was planned for the daily production. Each product was evaluated after each production experiment, and changes to the recipe were made if necessary. For successful product recipe samples, nutritional value was determined and changes to the recipe were performed if necessary.

In this study, no preservatives, colorants or flavour enhancers were added. The used ingredients are listed in Table 4.

For suspension stabilisation during the processing, different thermo-vulnerable gums were used, which break down under heat during the sterilisation process in a retort.

MC packaging. It is crucial for a $\mathrm{MC}$ to be convenient in usage and be safe for the consumer - it should not be fragile or harm the consumer in the case of a fall on the pocket that contains the MC. For our purposes, 5-layer laminated retort pouches (lacquer-polyester-aluminum-nylon-polypropylene) were used. For more convenient use, it was decided to choose pouches with a bottom - Doypack type packaging, produced by C. L. P Industries Ltd. "Tadbik" (Kibbutz Negba, Israel).

Table 4. Main course ingredient list

\begin{tabular}{|c|c|c|}
\hline No & Main course & Ingredients \\
\hline 1 & $\begin{array}{l}\text { Cabbage stew } \\
\text { with ham }\end{array}$ & $\begin{array}{l}\text { Thermally processed ham, fresh potatoes, } \\
\text { sauerkraut, water, fresh onions, fresh carrots, } \\
\text { sugar, tomato paste, canola oil, rice protein, } \\
\text { fresh garlic, salt, seasonings }\end{array}$ \\
\hline 2 & $\begin{array}{l}\text { Beef goulash } \\
\text { with buckwheat }\end{array}$ & $\begin{array}{l}\text { Water, thermally processed beef, buckwheat, } \\
\text { fresh champignons, rapeseed oil, tomato paste, } \\
\text { fresh onions, flax seeds, whey protein, } \\
\text { stabilisers, flour, sugar, salt, seasonings }\end{array}$ \\
\hline 3 & $\begin{array}{l}\text { Pea porridge } \\
\text { with smoked pork }\end{array}$ & $\begin{array}{l}\text { Water, thermally processed bacon, dried yellow } \\
\text { peas, smoked ham, onions, fresh carrots, canola } \\
\text { oil, pea protein, starch, salt }\end{array}$ \\
\hline 4 & Pasta Bolognese & $\begin{array}{l}\text { Water, minced ham, pasta, tomato paste, fresh } \\
\text { carrots, fresh onions, starch, fresh garlic, salt, } \\
\text { seasonings }\end{array}$ \\
\hline
\end{tabular}

5 Lentils with chicken Water, thermally processed chicken fillet, and vegetables lentils, fresh champignons, frozen green peas, canola oil, starch, stabilisers, salt

6 Mashed potatoes Water, minced ham, fresh potatoes, whey with meatballs

7 Chili con carne

8 Rice with smoked salmon

9 Vegetable stew with chicken protein, stabilisers, starch, salt seasonings

Water, thermally processed ham, red beans, tomato paste, fresh carrots, canned corn, fresh onions, lentils, bean protein, canola oil, fresh garlic, salt, seasonings

Water, thermally processed salmon fillet, rice fresh carrots, green peas, canned corn, fresh onions, rapeseed oil, rice protein, fresh garlic, stabilisers, salt, seasonings

Thermally processed chicken fillet, water, fresh potatoes, green peas, green beans, fresh carrots, canola oil, fresh paprika, pearl barley, cream, fresh garlic, sugar, salt, seasonings, stabilisers 
MC retort sterilisation. The sterilisation process (KirseOzolina et al., 2019) was performed in a PANINI SN4280 steam-air retort (Panini Ltd., Italy) at Kronis Ltd. production facilities. The calculated $\mathrm{F}_{0}$ value for all samples was $20 \pm 5$ minutes. Throughout the experiment, the following retort programme setpoints were set:

1) preliminary step: steam inlet and outlet are open until the references resistance-type thermocouple (Pt100), which controls the process, indicates $80{ }^{\circ} \mathrm{C}$;

2) come-up (CUT) phase: $20 \mathrm{~min}$ to $118{ }^{\circ} \mathrm{C}$;

3) holding phase: $70 \mathrm{~min}$ at $118^{\circ} \mathrm{C}$, overpressure $1.7 \mathrm{bar}$;

4) cooling phase: $60 \mathrm{~min}$, or until the references packaging (with thermocouple inside) achieves $20{ }^{\circ} \mathrm{C}$.

Chemical analysis. Chemical analyses were performed at the laboratories of J. S. Hamilton Baltic Ltd. and the used methods are summarised in Table 5. Salt content was calculated by multiplying the measured sodium with a factor of 2.5 .

Table 5. Methods of chemical analysis

\begin{tabular}{ll}
\hline \multicolumn{1}{c}{ Parameter } & \multicolumn{1}{c}{ Method } \\
\hline $\begin{array}{l}\text { Protein }\left(N^{*} 6.25\right) \\
\text { Energy value }\end{array}$ & $\begin{array}{l}\text { PB-116 ed. II of 30.06.2014 } \\
\text { Calculated according to Regulation (EU) No } \\
\text { 1169/2011 } \\
\text { Fat }\end{array}$ \\
Total carbohydrates & Calculated by difference \\
Dietary fibre & AOAC 991.43:1994 \\
Salt (Na*2.5) & $\begin{array}{l}\text { Flame atomic absorption spectroscopy method } \\
\text { (FAAS), PB-318/FAAS, ed. I of 27.07.2015 }\end{array}$
\end{tabular}

Proteinogenic AA High-performance liquid chromatography method with spectrophotometric detection (HPLC-UV/Vis) and diode array detection (HPLC-DAD), PB-53/HPLC ed. II of 30.12.2008

Tryptophan

High-performance liquid chromatography method with fluorescence detection (HPLC-FLD), PB-136/HPLC ed. I of 06.02.2012

Data processing. Data processing was performed with MS Office Excel v16 software. Results were given as mean values. A $p$-value less than 0.05 was considered as statistically significant.

\section{RESULTS}

Market analysis. Market analysis showed (Table 3) that the greatest variety of ready-to-eat meals with a long shelf-life (i.e. $>2$ years) is produced in the United Kingdom $(n=48)$ and most of the MC meals are preserved using freezedrying $(n=135)$, which contributes to $73 \%$ of analysed samples.

Complete sample analysis shoved (Fig. 1), that $41 \%$ of MC were based on red meat, $30 \%$ were vegetarian, $24 \%$ contained white meat, and $5 \%$ of the products were seafood based.
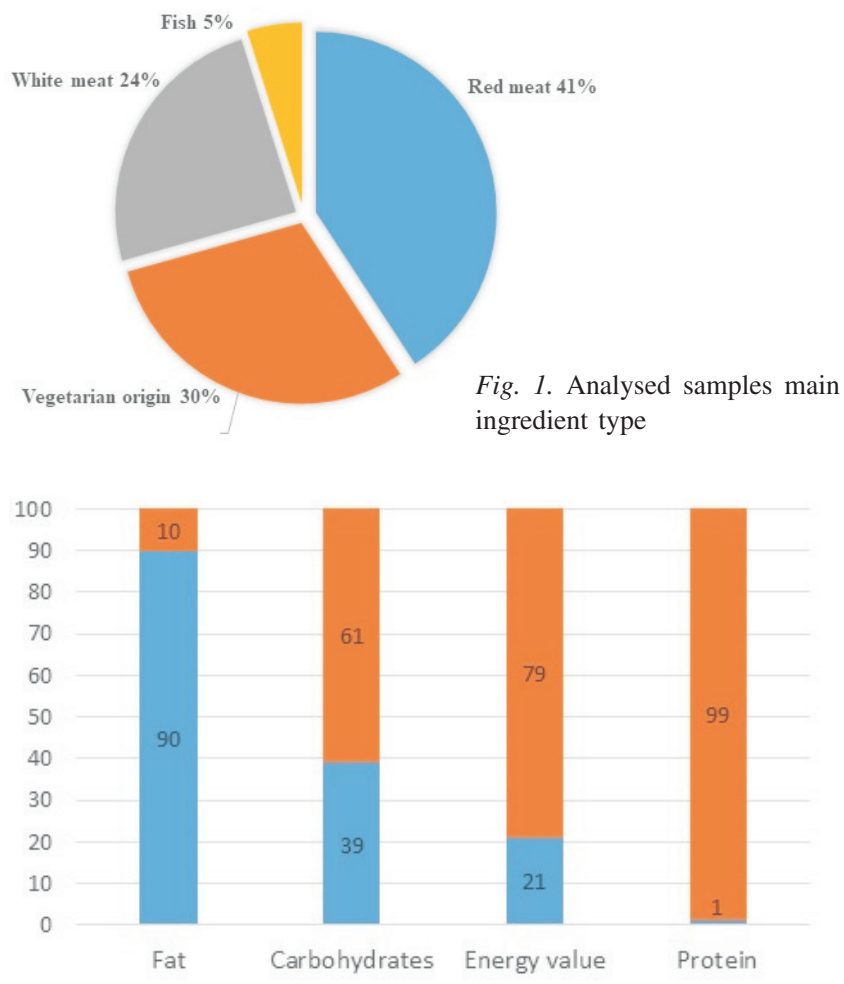

Fig. 2. Analysed foods that meet certain criteria, \%

Data showed (Fig. 2), that among the 184 products on the EU market, 165 products met the criteria of not more than $8.4 \mathrm{~g}$ fat per $100 \mathrm{~g}$ of the product, 71 products did not exceed $12.5 \mathrm{~g}$ carbohydrates per $100 \mathrm{~g}$ of the product, 39 products provided at least $140 \mathrm{kcal} / 100 \mathrm{~g}$, and only two products contained $10.0-14.3 \mathrm{~g}$ protein per $100 \mathrm{~g}$ of product.

Developed product nutritional value and amino acid content. The nutritional analysis of developed MC with ingredients characteristic to the Baltic region showed (Table 6 ) that all samples were within the formulated requirements.

Table 6. Nutritional value of developed main course samples

\begin{tabular}{c|c|c|c|c|c|c}
\hline \multirow{2}{*}{ MC $^{1}$} & \multirow{2}{*}{$\begin{array}{c}\text { Energy } \\
\text { value, } \\
\mathrm{kca} \cdot 100 \\
\mathrm{~g}^{-1}\end{array}$} & \multicolumn{5}{|c}{ Nutrient, g.100 g-1 } \\
\cline { 3 - 7 } & 160.0 & 10.0 & 12.0 & 8.0 & 1.0 & 1.10 \\
\hline 1 & 160.0 & $\begin{array}{c}\text { Carbohyd- } \\
\text { rates }\end{array}$ & Fat & $\begin{array}{c}\text { Dietary } \\
\text { fibre }\end{array}$ & Sodium \\
2 & 140.6 & 10.0 & 12.5 & 5.6 & 1.0 & 0.75 \\
3 & 150.9 & 10.0 & 9.0 & 8.3 & 1.3 & 0.92 \\
4 & 163.1 & 10.0 & 12.5 & 8.1 & 1.9 & 0.90 \\
5 & 140.0 & 11.9 & 9.0 & 6.2 & 3.0 & 0.68 \\
6 & 153.4 & 10.3 & 12.2 & 7.2 & 0.5 & 1.08 \\
7 & 140.1 & 10.0 & 10.0 & 6.7 & 3.8 & 0.88 \\
8 & 141.4 & 10.0 & 12.4 & 5.7 & 1.3 & 1.05 \\
9 & 142.5 & 10.7 & 12.3 & 5.6 & 1.3 & 0.52 \\
$\mathrm{AM}^{2}$ & 136.0 & 11.0 & 15.0 & 3.5 & N/A & 1.2 \\
$\mathrm{LYO}^{3}$ & 116.2 & 10.2 & 13.4 & 1.8 & 2.7 & 1.1 \\
\hline
\end{tabular}

${ }^{1}$ MC, main course; ${ }^{2}$ Adventurer menu (AM, Czech Republic) - Farmer ham with lentil ragout; ${ }^{3}$ LYO FOOD Expedition (Poland) - Beef stroganoff 
Adventurer menu (Czech Republic) and LYOFOOD (Poland) products did not meet all defined criteria in this work, but they still were analysed because they were the only two products that met minimum protein content. To meet optimum daily dietary fibre content, $100 \mathrm{~g}$ of product should contain at least $2.5 \mathrm{~g}$ dietary fibre, with the condition that three portions of MC is the only food consumed. Such criteria is met by two of the developed products and the LYOFOOD sample. Salt consumption of max $6 \mathrm{~g} / \mathrm{day}$ will be exceeded if $100 \mathrm{~g}$ of the product contains $0.5 \mathrm{~g}$ sodium.

Amino acid composition of the developed products was expressed as a function of daily amino acid requirements (Table 2), where $100 \%$ indicated that the given AAs amount fulfils the necessary daily requirement. The data showed that all developed MCs were able to provide the consumer with recommended minimal amounts of essential AAs (Table 7), and even exceed it at by least twice.

\section{DISCUSSION}

It can be clearly seen that freeze-drying technology prevails among the MRE manufacturers. Use of such technology means that the consumer must be able to add pre-heated fresh water to the product or add cold water and heat the whole packaging, which is an alternative to thermostabilised ready-to-eat foods. Thermostabilised foods differ from lyophilised foods in that there is no risk factor such as lack of bottled or fresh water.

The lack of samples with enough protein on the EU market (Fig. 2) is mainly related with uncommonly high overall nutrient density, which should be achieved in a ready meal in terms of the framework (section "Framework formulation"). During the development of the products, it was concluded that, with addition of protein concentrates, it is possible to achieve certain criteria, but product acceptance dropped accordingly. Protein concentrates that were used in this study added off-flavours to the products and some had sandy mouthfeel, which was observed previously by others re- searchers as well (Nogueira, and Steel, 2018). Added concentrates bound the available water, lowering the viscosity of the product, which led to difficulties in the pumping technological process. Besides that, it was found that products with meat with high fat content (i.e. $>16 \%$ ) were accepted significantly better than products with lean meat $(p<$ 0.05 , data not shown). On the other hand, it was much more difficult to achieve protein requirements with fatty meat, without using protein concentrates. The use of lean meat consequently solves the protein requirement issue, but creates feeling of lack of flavour and moisture in the dish. Therefore, it was decided to use lean meats in products with added sauce (i.e. Beef goulash, Cabbage stew, Pasta Bolognese, Mashed potatoes, Chilli con carne), while fatty meats were used in dishes where sauce was not applicable (Pea porridge, Lentils with chicken, Rice with salmon, Vegetable stew with chicken).

It was concluded that if a MC contains $10 \mathrm{~g}$ of protein per $100 \mathrm{~g}$, consumed thrice a day it will provide at least the minimum recommended amount of every essential amino acid. Nonetheless, there is evidence that amino acid oxidation rises during the physical activity, which leads to higher demand for amino acids (Tarnopolsky, 2004).

The developed products nutritional values fully align with modern recommendations for "normal" military operations, with the condition that the consumer will use the MC thrice a day with all other components of the MRE. However, if the MC would be consumed alone, it still would deliver the minimal daily amount of protein, i.e. $118 \mathrm{~g} /$ day.

\section{CONCLUSIONS}

In conclusion, it is clearly seen that the EU market lacks ready meals with high nutrition value, necessary for a consumer with huge physical activity level. However, it is possible to achieve the necessary nutrition with specifically developed products, which have higher nutrient density, as demonstrated in the presented paper.

Table 7. Amino acid composition balance ${ }^{1}, \%$

\begin{tabular}{c|c|c|c|cccc|c|cc|cc}
\hline MC $^{2}$ & Trp & Thr & Ile & Leu & Lys & Met & Cys & Tyr & Val & His \\
\hline 1 & 262 & 243 & 175 & 175 & 233 & 241 & 141 & 115 & 158 & 304 \\
2 & 380 & 324 & 228 & 226 & 284 & 256 & 222 & 146 & 204 & 319 \\
3 & 319 & 284 & 213 & 210 & 263 & 226 & 207 & 140 & 181 & 334 \\
4 & 357 & 324 & 235 & 234 & 243 & 301 & 219 & 146 & 210 & 365 \\
5 & 366 & 372 & 241 & 241 & 296 & 312 & 231 & 160 & 217 & 357 \\
6 & 368 & 577 & 220 & 230 & 273 & 316 & 289 & 164 & 199 & 349 \\
7 & 349 & 334 & 228 & 238 & 284 & 271 & 185 & 152 & 204 & 395 \\
8 & 501 & 486 & 327 & 327 & 405 & 496 & 322 & 243 & 321 & 425 \\
9 & 395 & 405 & 304 & 284 & 385 & 391 & 263 & 176 & 257 & 365 \\
$\mathrm{AM}^{3}$ & 406 & 415 & 319 & 312 & 385 & 301 & 230 & 188 & 280 & 441 \\
LYO $^{4}$ & 274 & 242 & 184 & 184 & 208 & 219 & 210 & 101 & 163 & 286
\end{tabular}

\footnotetext{
${ }^{1}$ Amino acid (AA) composition of the developed products is expressed as a function of daily amino acid requirements (Table 2), where $100 \%$ indicates that the given AAs amount is fulfilling necessary daily requirement.

${ }^{2}$ MC, main course; ${ }^{3}$ Adventurer menu (AM) Czech Republic) - Farmer ham with lentil ragout; ${ }^{4}$ LYO FOOD Expedition (Poland) - Beef stroganoff
} 


\section{ACKNOWLEDGMENTS}

The present research leading to these results in accordance with contract No. 1.2.1.1/18/A/002 between Latvian Food Competence Centre Ltd. and the Central Finance and Contracting Agency (08.05.2019) was conducted by Kronis Ltd. with the support of the European Regional Development Fund (ERDF) within the framework of the Latvian Food Industry Competence Centre.

\section{REFERENCES}

Kaminski, M., Skonieczna-Zydecka, K., Nowak, J. K., Stachowska, E. (2020). Global and local diet popularity rankings, their secular trends, and seasonal variation in Google Trends data. Nutrition, 79-80; 10759.

Kirse-Ozolina, A., Muizniece-Brasava, A., Raits, A., Kruma, Z. (2019). Effect of sterilization parameters of the quality of commercially prepared instant soups. In: Engineering for Rural Development, 22-24 May 2019, Jelgava, pp. 695-704.

NATO (2010). Nutrition Science and Food Standards for Military Operations. RTO Technical Report TR-HFM-154: Final Report of RTO Task Group RTG-154. Research and Technology Organization of the North Atlantic Treaty Organization.
NATO (2013). Allied Medical Publication AMedP-1.11 Edition A Version 1 (2013). Requirements of Individual Operational Rations for Military Use. NATO Standardisation Agency (NSA).

NHMRC (2006).National Health and Medical Research Council. Nutrient Reference Values for Australia and New Zealand Including Recommended Dietary Intakes. Australian Government Department of Health and Ageing, New Zealand Ministry of Health. 254 pp.

Nogueira, A. C., Steel, C. J. (2018). Protein enrichment of biscuits: A review. Food Rev. Int., 34 (8), 796-809.

Report of a Joint FAO/WHO/UNU Expert Consultation (2004). Human energy requirements. FAO Food and Nutrition Technical Report Series No. 1; Rome. 96 pp.

Report of a Joint FAO/WHO/UNU Expert Consultation (2007). Protein and Amino Acid Requirements in Human Nutrition. WHO technical report series No. 935, Geneva. 265 pp.

Rodriguez, N., DiMarco, N., Langley, S. (2009). Position of the American Dietetic Association, Dietitians of Canada, and the American College of Sports Medicine: Nutrition and athletic performance. J. Amer. Dietetic Assoc., 109 (3), 509-527.

Tarnopolsky, M. (2004). Protein requirements for endurance athletes. Nutrition, 20 (7-8), 662-668.

Received 20 March 2021

Accepted in the final form 2 November 2021

\section{TIRGUS IZPĒTE UN ĒŠANAI GATAVAS MALTĪTES PAMATĒDIENA IZSTRĀDE MILITĀRĀS IZMANTOŠANAS KONTEKSTĀ}

Vienas dienas uzturs karavīram var tikt nodrošināts ar 1 uzturdevas paku ēšanai gatavas maltītes uz 24 stundām vai 3 pakas ēšanai gatavas maltītes, kas atbilst 24 stundu uzturam. Pēc fiziskās aktivitātes līmeṇa militārās operācijas var iedalīt divās kategorijās: normālās operācijas, kas salīdzināmas ar pilsētas policijas darbu un ugunsdzēsības darbiem, un kaujas operācijas, ko raksturo kājnieku misijas. Pētījuma mērkị bija: a) analizēt ES tirgū esošos pamatēdienus mīkstā iepakojumā (n = 184), militārās izmantošanas kontekstā, un b) izstrādāt termostabilizētus pamatēdienus, kas atbilst mūsdienu veselības un uztura rekomendācijām militārām vajadzībām, t.i., olbaltumvielu, og̣hidrātu, tauku, kopējās enerǵijas un neaizstājamo aminoskābju sastāvam. Lielākais pamatēdienu daudzums ar derīguma termiņu ilgāk par vienu gadu tiek ražots Lielbritānijā $(n=48)$, un vairums no pamatēdieniem ir konservēti žāvēšanas procesā ar sublimācijas metodi ( $\mathrm{n}=135) .90 \%$ analizēto paraugu ir nepieciešamais tauku daudzums fiziski aktīvam patērētājam (t.i., karavīram), 39\% ir nepieciešamais og̣̣hidrātu daudzums, $21 \%$ atbilst enerǵêtiskajām prasībām, bet tikai $1 \%$ no produktiem spēj sasniegt olbaltumvielu daudzuma prasības. Šajā pētījumā tika izstrādāti deviṇi pamatēeieni ar derīguma termiṇu trīs gadi, kas spēj nodrošināt fiziski aktīvu patērētāju ar nepieciešamo olbaltumvielu daudzumu, apmierinot aminoskābju un enerğijas nepieciešamības prasības. 